\title{
A HOMEOPÁTIA AZ ORVOSLÁSBAN
}

\section{HOMEOPATHY IN MEDICINE}

\author{
Sarkadi Balázs', Kálmán Zsófia² \\ 'professor emeritus, MTA Természettudományi Kutatóközpont \\ sarkadi@biomembrane.hu \\ ${ }^{2}$ föorvos, Bliss Alapítvány \\ sophiakalman@gmail.com
}

\begin{abstract}
ÖSSZEFOGLALÁS
A gyógyítás veszélyes foglalkozásában a tudományosan megalapozott, bizonyítottan hatékony gyógyszeres kezelés, és a kor - néha kifejezetten tudománytalan - igényeihez való alkalmazkodás egyaránt fontos feladat. Az "orvostudomány jelenlegi állásának megfelelő" kezelés sem mentes a tévedésektől és hibáktól, de a "Ne árts!" elvét szem előtt tartva, a lehető leghatékonyabban hivatott elősegíteni a betegek gyógyulását. Az áltudományos, olykor alternatívnak nevezett gyógymódok, így a homeopátia igen nagy veszélye, hogy az önmagában ártalmatlan, ám hatástalan készitmény is ártalmas, ha olyan súlyos betegséget kezelünk vele, amelynek ismert más, hatékony gyógykezelése. Ezért kivizsgálatlan betegnek placebót, illetve homeopátiás szert adni orvosi mühiba! Ugyanakkor a megfelelő esetekben a homeopátia toleránsan és a gyógyítás szempontjainak megfelelően - a placebohatás alapján - sokszor jól alkalmazható.
\end{abstract}

\section{ABSTRACT}

In medicine it is equally important to apply scientifically established safe and effective therapies as well as to cope with the - often non-scientific - expectations of the patients. Treatments based on the current state of medical science are not free of errors but these therapies still provide the best treatment options, when observing the rule of "nil nocere". The major danger of using pseudo-scientific treatments like homeopathy is that even a non-toxic, ineffective substance is harmful if we use it to treat a serious disease instead of a known, efficient cure. Thus, to apply a placebo or a homeopathic substance to a patient without proper diagnostic examination is considered a medical malpractice. At the same time, the use of the strong placebo-effect of a homeopathic substance under well-defined circumstances may help the physician to improve the patient's condition.

Kulcsszavak: a homeopátia története, tudomány és homeopátia, placebohatás, gyermekgyógyászat és homeopátia

Keywords: history of homeopathy, science and homeopathy, placebo effect, homeopathy in pediatrics 


\section{A HOMEOPÁTIA EREDETE, FELHASZNÁLT ANYAGAI, MÓDSZEREI}

A homeopátia Samuel Hahnemann német orvos kezdeményezésére indult el a 18. század végén. Magyar neve, a „hasonelvü gyógyítás” (homeo: hasonló; pathos: kór), jól tükrözi a módszer lényegét. Az elképzelés szerint - amely egyébként már Hippokratésznél is fellelhető volt ${ }^{1}$, a betegséget hasonló tüneteket okozó szerrel kell kezelni, például a lázat azokkal a hatóanyagokkal, amelyek nagy adagban maguk is lázkeltők. Ezt a gondolatot a magyar nyelv igen érzékletesen fogalmazza meg a „kutyaharapást szőrével” szólásmondásban.

Hahnemann a homeopátiás gyógyítás alapelveit 1790 körül dolgozta ki. Ekkoriban fordította angolból németre William Cullen A Treatise of the Materia Medica címü könyvét, amely a növényekböl elöállitható hatékony gyógyszerek, például a kinin lehetséges alkalmazásait mutatta be. A dél-amerikai kinafa (chinchona) kérgéből kinyerhetö kinin a váltóláz (malária) kezelésének elsö hatékony gyógyszere volt, ugyanakkor maga is lázat okozhatott. Ebböl jutott Hahnemann arra a következtetésre, hogy egy szer, amely egészséges emberben bizonyos tüneteket idéz elö, betegségben ugyanezen tüneteket gyógyithatja. Ezen gondolatmenet alapján állitotta össze a késöbbi évtizedek során számos további alapanyaggal kibövitett Materia Medica címü alapmunkáját. Ebbe a könyvbe olyan szerek kerülhettek, amelyek ismert méregként vagy túladagolás következtében köztudottan betegséget, tüneteket okoztak (Hahnemann, 1810; URL1; Thomas-Shealy, 1996; Freeman, 2009; Carlston, 2011; Lange, 2013). Más anyagokat önkénteseken próbáltak ki az ún. „homeopátiás bizonyítás” során. Tehát csak olyan anyag válhatott a hasonelvü gyógyítás eszközévé, amely átlagos használatkor bizonyítottan mérgező hatást fejtett ki. A hatásmechanizmust illetően az volt az alapelképzelés, hogy a betegség által megzavart életerő (vital force) helyreállítható egy másik megzavarással, amelyet különböző farmakológiás szerek, mérgek és gyógyszerek váltanak ki. E második megzavarást ezután a szervezet könnyebben le tudja küzdeni, így a gyógyszer csupán a saját életerő helyreállítását szolgálja. Ez az öngyógyító erő a homeopátia fontos filozófiai háttere (Hahnemann, 1810; URL1).

Hahnemann természetesen jól érzékelte, hogy a Materia Medica hatóanyagainak beadása veszélyes, sőt életveszélyes lehet, ezért azok jelentős hígítását javasolta. Így alakult ki a homeopátiás módszer lényege, az alkalmazott gyógyszerek veszélytelenné történő hígítása, homepátiás szaknyelven „dinamizálása” vagy „potenciálása”. Ennek során a folyékony alapanyagot - az ún. őstinktúrát vagy ősoldatot - alkohollal, tiszta vízzel vagy alkohol-víz keverékével történő tízszeres (jele X) vagy százszoros (jele C) hígítási sorozatnak kell alávetni. Szilárd, porjellegú alapanyagoknál ez általában tejcukorral (laktózzal) történik (Carlston,

\footnotetext{
${ }^{1}$ Hippokratész: Az emberi belső térről. 42.: „,...ha valami a betegséghez hasonló betegséget okoz, akkor ugyanez a valami magát a betegséget is meggyógyítja" (ford. Oláh Andor), 161.
} 
2011; Lange, 2013). Hahnemann úgy gondolta, hogy bár az eredeti hatóanyag ilyen módon szinte mérhetetlenül alacsony szintet ér el, a készítmény gyógyerejét éppen ez a dinamizálás növeli meg, teszi erőteljesebbé. Éppen ezért, a hatékonyság fokozása érdekében a homeopátiás kezelés során minél többször hígított, akár 30X, sőt 20-50C potenciájú szerek is alkalmazásra kerülnek. A dinamizálás során fontos az anyag megfelelö kezelése: a szukkusszió vagy ütve rázás során a frissen hígított oldatot az edény egy kemény, de elasztikus tárgyhoz, például egy bőrkötésủ könyvhöz történő ütögetésével, rázogatásával kellett megfelelően dinamizálni. A trituráció vagy dörzsölés a homeopátiás porok dinamizálását szolgálta, mozsárban, megfelelő törővel kellett végezni. A gyógyító alapanyagok között alkalmaztak még mind beteg szervekből (nozód), mind egészséges testrészekből (szarkód) nyert szövetdarabkákat, amelyeket ugyanígy dinamizáltak, illetve potenciáltak (a homeopátia alapjait részletesen lásd Hahnemann, 1810; URL1; Thomas-Shealy, 1996; Freeman, 2009; Carlston, 2011; Lange, 2013).

Az eredeti elképzelés szerint a Materia Medica gyógytárából kiválasztott és megfelelőképpen potenciált szerek a szervezet „vitális energiáinak” felerősítése révén győzik le a a betegségek vélt okozóit, a „miazmákat”. Hahnemann három miazmát nevezett meg - szifilisz, szikózis és spóra -, amelyeket az egyik modern homeopátiás elméleti munka (Reiner, 1982) így definiál: „A miazmák az élő anyagra ható bizonyos alapvető erők manifesztációi... Bennük a centripetális komponens konszolidációt, míg a centrifugális expanziót eredményez, a kettő együttesen ritmikus napi aktivitást. Az első hatás az asszimilációhoz, a másik a diffúzióhoz és az eliminációhoz rendelhetô.” Ma már kevés ember van, aki ezt a meghatározást ne tartaná zagyvaságnak.

\section{A HOMEOPÁTIA ÉS A TERMÉSZETTUDOMÁNYOK}

A mai molekuláris alapú farmakológiai gondolkodás szempontjából számos homeopátiás szer értelmezhetetlen, hiszen a hígítási sorozatokkal elért dinamizálás következtében feltehetően már egyetlen molekulát sem tartalmaz a Materia Medicában leírt eredeti hatóanyagból. A farmakológia számtalan kísérletes ténnyel támasztotta alá, hogy a gyógyszerek hatásai és mellékhatásai egyaránt az alkalmazott anyag koncentrációjától függnek. A klinikumban alkalmazott gyógyszerek nagy része millimólos $\left(10^{-3} \mathrm{M}\right)$, mikromólos $\left(10^{-6} \mathrm{M}\right)$, esetleg nanomólos $\left(10^{-9} \mathrm{M}\right)$ koncentrációban is hatásos lehet. Az élő szervezetben azonban pikomólos $\left(10^{-12} \mathrm{M}\right)$ koncentrációban ható gyógyszer alig fordul elő, s femtomólos $\left(10^{-15} \mathrm{M}\right)$, attomólos $\left(10^{-18} \mathrm{M}\right)$ vagy zeptomólos $\left(10^{-21} \mathrm{M}\right)$ koncentrációjú hatóanyagok nem ismertek. Egy homeopátiás készítményben a $20 \mathrm{X}$ vagy $10 \mathrm{C}$ potenciálás okozta higítás $\left(10^{-20}\right)$ már az attomólnál is kisebb koncentrációt jelent, és egy igazán dinamizált homeopátiás készítmény még ennél is nagyobb hígítással 
készül. Ha egy mólnyi anyagból $\left(6 \times 10^{23}\right.$ molekula) indulunk ki, a $24 \mathrm{X}$ vagy $14 \mathrm{C}$ potenciálás azt jelenti, hogy csak ötven százalékos valószínűsége marad annak, hogy akár egyetlen molekula is jelen lenne a teljes készítményben. A homeopátia tréfás kritikájaként találták ki a Marx testvérek filmjein nevelkedett kémikusok a Zeppomol $\left(10^{-24}\right)$, Harpomol $\left(10^{-27}\right)$ és Grouchomol $\left(10^{-31}\right)$ egységeket, amelyek az egy molekulánál kevesebb anyagot tartalmazó homeopátiás oldatokra (25X és $15 \mathrm{C}$ felett) lennének alkalmazhatók (Science Jokes).

Ha a molekuláris farmakológia logikája ellenére a homeopátiás készítmények mégis hatásosnak bizonyulnak (lásd később), milyen tudományos magyarázatot lehet erre adni? Hahnemann és követőinek elképzelése szerint a hígítás során az eredeti hatóanyagok mintegy „nyomot hagynak” az oldószer szerkezetében, ez adja a dinamizálás alapját. Az ütve rázás vagy a dörzsölés hatására (igaz, nem tudjuk, hogy a mai nagy, modern technológiákkal dolgozó gyógyszergyárakban is így történik-e az elő́llítás) az oldószer molekulái „emlékeznek” a feloldott molekulákra, még azután is, hogy az oldott anyag már nincs jelen. Sőt, ez az emlékezés annál hatékonyabb, minél sokszorosabb a hígítás és rázogatás. Minderre azonban semmilyen bizonyíték nincsen, hiszen a víz vagy az alkohol szerkezeti „emlékezete” legfeljebb a másodperc tört részéig terjed, így ez az elmélet kifejezetten ellentmond a fizika, farmakológia és biológia kísérletes eredményeinek.

Érdekes tudománytörténeti eset a világszerte olvasott tudományos folyóiratban, a Nature-ben 1988-ban megjelent cikk, amely arra utal, hogy a homeopátiás módon hígított anyag mégiscsak hatásos lehet egy jól meghatározott kísérleti rendszer keretei között. A nemzetközileg jelentős immunológusként elismert, az egyik nagy francia intézetet vezető Jacques Benveniste kutatólaboratóriumából tizenkét kiváló társszerző nevével fémjelzett, nagy érdeklődést kiváltott közlemény (Davenas et al., 1988) jelent meg. A tanulmány szerint az emberi immunrendszer fontos szereplöi, a bazofil leukociták, aktiválhatóak voltak az antitestek olyan mértékü hígítása esetében is, amely már egyetlen molekulát sem tartalmazott az eredeti szérumból. A bírálók erős kétkedése és a szerkesztő habozása ellenére végül mégis megjelent a közlemény, amelyben a szerzők azzal magyarázták a különleges jelenséget, hogy a víz szerkezetének megváltozása mintegy megőrizheti az antitestek nyomát a készítményben. A homeopátiás orvoslás lelkesedéssel fogadta ezt a tudományos eredményt, amelynek azonban legfőbb problémája az, hogy azóta sem sikerült senkinek megismételnie. Bár a cikket a szerzők nem vonták vissza, a Nature szerkesztője, John Maddox a sok kritikus vélemény, és az ismételten negatív eredményeket adó, világszerte elvégzett, sikertelen kísérletek hatására elhatározta, hogy Benveniste saját laboratóriumában fogja ellenőrizni ezeket az eredményeket. A vizsgálathoz fekérte társul a tudományos csalások leleplezésének nagy szakértőit, James Randi büvészt és Walter Stuart jogi szakértőt, így hármuk személyes ellenőrzése mellett végezték el újra Benveniste munkatársai a laboratóriumi vizsgálatokat. Az eredmény egyértelmü volt: a leírt hatás 
nem létezett! Az újabb Nature cikk, most már a három „ellenőr” tollából (Maddox et al., 1988) egyértelmüen megcáfolta az eredeti kísérleti eredményeket. Ám ezzel sem Benveniste-et, sem a homeopátia hívőit nem sikerült meggyőzni, és Benveniste cikke máig a homeopátiás hígítás biológiai hatásának hivatkozásaként jelenik meg (lásd Falus András cikkét, 2004).

A tudományos csalásokra nincs mentség, de ha egy eljárásnak nincs tudományos magyarázata, attól az még lehet hatékony, hiszen ma sem ismerjük minden jelenség pontos hátterét. Az ostor már évszázadok óta pattogott, amikor kiderítették, hogy az ostor végének sebessége meghaladja a hangsebességet, és tulajdonképpen kisméretű hangrobbanás történik. Az aszpirin hatásmechanizmusát sem ismertük évszázadokig, mégis a legelterjedtebb, igen hatékony lázcsillapítóként használták ugyanezen évszázadok alatt. Lehet, hogy ez a helyzet a homeopátia módszereivel is?

A legnagyobb probléma az, hogy magára a homeopátiás kezelés hatékonyságára nincsenek igazi bizonyítékok. Az eredmények ,anekdotikusak”, valódi kísérletes körülmények között, azaz kettős vak, placebokezeléssel összevetett, korrekt, megismételhető vizsgálatok vagy nem történtek, vagy hatástalanságot mutattak (lásd Ernst, 2005; Shang et al., 2005). Az ausztrál Nemzeti Egészségügyi és Orvosi Kutatási Tanács (NHMRC) 1800 vizsgálat összehasonlító elemzése kapcsán 2015-ben arra az eredményre jutott, hogy semmilyen értékelhető adat nem támasztja alá a homeopátiás szerek hatékonyságát (NHMRC, 2015). Az Európai Akadémiák Tudományos Tanácsadó Testülete, az EASAC 2017-ben állásfoglalást adott ki arról, hogy a homeopátia tudománytalan, alapelvei ellentmondanak a fizika és a kémia törvényeinek, és soha nem jelent meg egyetlen valódi bizonyíték sem, ami igazolná a homeopátiás gyógymódok hatékonyságát (EASAC, 2017).

\section{A HOMEOPÁTIA ÚTJA, SIKERÉNEK MÉRÖLDKÖVEI}

Hahnemann-nak a 19. század elején megjelent müvei, így az Organon der rationellen Heilkunde és a Reine Arzneimittellehre nyomán igen gyorsan terjedt a homeopátia alkalmazása. A korabeli orvoslás meglehetősen durva és gyakran namcsak hatástalan, de kifejezetten káros módszereivel - lásd érvágás, hashajtás, gyógynövény-készítmények óriási adagjai - szemben a homeopátia szelíd gyógymód volt, s legalább nem okozott súlyos mellékhatásokat. Filozófiája, a beteg öngyógyulását elötérbe helyező attitüdje is segítette elterjedését.

A 19. században a homeopátiás orvoslás jelentős hatást gyakorolt az orvoslás egészére. Az első homeopátiás klinika megnyitása után egész Európában gyorsan terjedtek a hasonló orvosi mühelyek, és folyamatosan harcban álltak a korabeli hivatalos orvoslással. Így például a Habsburg Birodalom területén először császári rendelettel betiltották, majd a tiltást visszavonva, gyakorlatilag engedélyezték 
a homeopátia alkalmazását, amely a 19. század végéig számos előnyt mutatott a tudományosan ugyanúgy alig megalapozott, ám hivatalosan elismert orvosi beavatkozásokkal szemben. Az 1840-es években megjelent tanulmányában a hagyományos orvoslás egyik vezető képviselöje elismerte, hogy a „minden racionális gondolkodást hiányoló", homeopátiás hígítással elóállított készítmények egyáltalán nem kevésbé hatékonyak, mint az akkor általánosan elfogadott és alkalmazott, „allopátiás” orvosi módszerek (idézi Vandenbroucke, 2005).

A 20. századra azonban megváltozott a helyzet: az emberi test és a gyógyszerhatások megismerése, az élettan és a farmakológia gyors fejlődése nyomán a homeopátiás kezelések elveszítették előnyüket. Az USA-ban az utolsó, tisztán homeopátiás orvosegyetem 1920-ban zárta be kapuit, bár a módszer továbbra is használatban maradt, és az 1970-es évektől, a „holisztikus” és természetgyógyász megközelítések előtérbe kerülésével szinte újraéledt. Természetesen a placebohatás ma is a gyógyítás és a gyógyulási folyamat igen fontos része, $\mathrm{s}$ ebben a homeopátiának is fontos szerep juthat (lásd alább).

Ma nehéz pontosan felmérni, hogy a különböző országokban milyen mértékben alkalmaznak homeopátiás szereket, mivel ez a legtöbb országban valamilyen módon beépült az orvosi gyakorlatba, és meghatározott engedélyezési lépéseken is átesett (lásd Zhang, 2001). Míg ma az USA-ban és Európában a homeopátiás szerek a gyógyszeres kezelés csak viszonylag kis részét, legfeljebb mintegy 10 százalékát alkotják, Indiában, ahol a természetgyógyászat az orvoslás szervesebb része, igen magas szinten ( $30 \%$ felett) használják őket. Minden korunkbeli felmérés arra utal, hogy a homeopátiás készítmények gyógyszerként történő alkalmazása a fejlett világban erősen csökken, ugyanakkor, érdekes módon, ez a visszaesés alig jellemző a gyermekgyógyászatra (lásd alább).

\section{A PLACEBOHATÁSÉS A HOMEOPÁTIA}

Az orvosi müködésben jól ismert és eredményesen felhasználható az ún. placebohatás (placebo: tetszeni, használni fogok). A placebo - tabletta, injekció vagy bármilyen más típusú készítmény, esetleg ártalmatlan beavatkozás formájában alkalmazása valódi orvosi kezelésnek tűnik, ám az soha nem tartalmaz akár az egészséget, akár a betegséget befolyásoló, aktív hatóanyagot. A számos anekdotikus példával, de tudományos vizsgálattal is hitelesen alátámasztott hatás az elmemúködés - egyes vizsgálatok szerint a tudat által múködtetett mediátoranyagok felszabadulása - és a testi reakciók közötti szoros kapcsolatot mutatja (lásd Ross-Olson, 1981; Ernst, 1990; Gensini et al., 2005). A „gyógyszer” meggyőző alkalmazása, annak formája, színe vagy mérete, a terapeuta viselkedése, de a páciens érékenysége és a hatás észlelésére mutató vágy is felerősíti a placebo hatását („,A jó orvosság vagy csíp, vagy keserü, de legalábbis drága”). Adott esetben, ha 
az előzetes várakozás ezt felerősíti, a placebo megjósolt „,súlyos mellékhatásai” is megjelenhetnek. Ez a jól ismert „nocebo” (ártani fogok) effektus.

A placebohatás elkerülhetetlensége ma már kötelezővé teszi, hogy minden új gyógyszert placebokontroll mellett vizsgáljanak, és sem a vizsgálatot végző orvos, sem a betegek nem tudhatják, hogy ki kap gyógyszert és ki placebót. Akármilyen furcsa, de nagyon sok, elöször hatásosnak gondolt gyógyszer vérzett el az így elvégzett, szigorú vizsgálatok során (Finnis et al., 2010).

A placebo és így a homeopátiás kezelés gyakori sikerének hátterét az adhatja, hogy a betegek két nagy csoportjának esetében a modern orvoslás tehetetlen. Az egyik csoportot azok alkotják, akiknek nincs a mai orvoslás eszközeivel megállapítható szervi betegségük, de súlyos tüneteik alapján mindenképpen kezelésre szorulnak. A másik csoportot azok jelentik, akik az orvostudomány jelenlegi állása szerint gyógyíthatatlan betegségben szenvednek. E két csoportba tartozó betegek fordulnak leggyakrabban a „nem tudományos” gyógykezelésekhez, így a homeopátiás orvosláshoz is.

\section{MIÉRT ÉS HOGYAN HASZNÁLJÁK MA IS A HOMEOPÁTIÁT?}

A mai homeopátiás ajánlások szerint az alacsony potenciájú szereket (D6-D15 vagy C6-C12) akkor alkalmazzák, ha föleg testi tüneteken szeretnének segíteni, a közepes potenciát (D30, C15, C30) akkor, ha a probléma egyforma súllyal van jelen a testi és a lelki síkon, míg a magas potenciájú szerek (D200, C200 és ennél magasabb) elsősegélyként, illetve lelki tünetek esetén javasoltak (lásd Jonas et al., 2003).

Ha igaz az, hogy a leghatékonyabbnak tartott szerekben már egyetlen molekulányi hatóanyag sincs, illetve még az egyetlen molekulára is csak egy „Harpomólnyi” az esély, vajon hogy maradhatott fenn a mai napig a homeopátiás terápia, ennyire hatékonyan ellenállva minden tudományos és tapasztalati kritikának? Miért indukál még mindig indulatokat pró és kontra? Kétségtelen ugyanis, hogy akik hisznek benne, ugyanolyan indulattal védik, mint amilyen hevesen ellenzői támadják. Érdekesen mutatkozott meg ez kicsiben, két régi kolléga találkozásakor, amikor egyikük elmesélte, hogy átváltott a homeopátiára, és most homeopátiás orvosként jegyzi magát. „Ne mondj semmit” szólt figyelmeztetőn, ,én a homeopátián nem vitatkozom. Annyira evidens, hogy aki nem látja, azt úgysem lehet meggyőzni. Hát mit mond a népi gyógymód a náthára? Igyál hagymateát! És mit csinál a hagyma, amikor vágod? Folyik tőle a szemed és az orrod. S amikor a náthától történik ugyanez, akkor ennek nyilván a hagyma a legjobb ellenszere. Hasonlót hasonlóval. Évezredek óta tudják."

Kétségtelen, hogy a mai napig igen sokan hisznek a homeopátiában, ki meggyőződésből, ki hitből, más üzleti érdekből. Nyilván változatosak az okok, jelen 
írásban mindössze néhány gyógyszerész véleményét és egy hosszú gyermekgyógyászi pálya tapasztalatait gyüjtöttük össze. Gyógyszerészek szerint ma föleg a fiatal, egészségtudatos, általában iskolázott nők használnak homeopátiás készítményeket elsősorban gyermekeik és kisebb mértékben családjuk számára. Idősebb betegek csak akkor vásárolnak homeopátiás szert, ha az orvos azt írja fel számukra. Sokszor nem is tudják, hogy amit bevesznek, az „nem rendes” gyógyszer, hanem valamilyen homeopátiás szer. A gyógyszerészek elmondása szerint amúgy is teljes a kuszaság a gyógynövények és a homeopátiás szerek általános ismeretében, e kettő alaposan keveredik a vásárlók fejében.

Ugyancsak jellemző, hogy a természetgyógyászati szerek, a bioélelmiszerek és a homeopátiás szerek hasonló vásárlói körben használatosak („,Én a gyerekeimnek kizárólag homeopátiás szereket adok, hiszen mindenre allergiásak, ezért glutén- és tejfehérjementes étrenden tartom öket, csak nyírfacukrot használunk, biopiacon vásárolunk.”). Láz, köhögés, „immungyengeség”, allergia, étvágytalanság, fejfájás, székrekedés, hasmenés, nyugtalanság, soványság, figyelmetlenség: mindenre akad homeopátiás szer, amihez nem kell recept, nincs sorbanállás a rendelöben a többi beteg gyerek között, és nincs az a hosszú lista a szörnyü mellékhatásokkal, amelyeket minden szülő gondosan végigböngész. Ha mégis elmennek a rendelőbe, akkor is gyakran felülbírálják az orvos javaslatát („Igaz, hogy végül mégis elmentünk az orvoshoz, fel is írt valami antibiotikumot, de ki sem váltottam. Kértem valami jó homeopátiás szert meghülésre és torokfájásra, ezek aztán szépen meggyógyították a gyereket”). A homeopátia felé fordulásban így jelentős szerepe lehet a mértéktelen és meggondolatlan antibiotikum-adásnak, $\mathrm{s}$ annak a sok ál- és rémhírnek, ami az interneten terjed az antibiotikumokkal kapcsolatban. Ám érdemes tudni, hogy gyermekeknél a legtöbb banális betegség magától is meggyógyul, és a gyógyszer gyakran inkább a szülő türelmének megnyerését szolgálja: legyen türelme kivárni a természetes gyógyulást... Így való igaz, hogy sok esetben a fölöslegesen adott antibiotikum helyett jobb lehet egy ártalmatlan homeopátiás szer. Szívesen fordulnak homeopátiához akkor is, ha az adott konkrét panaszra nincs kifejezetten ható gyógyszer. („Például gyakran kérnek valamit kifejezetten rekedtségre”, mondja a gyógyszerész. „Megnyugtatja a szülőt, hogy látja, direkt rá van írva, Rekedtség ellen. És mivel nincs mellékhatása, egész sokáig is adják.”)

A fó veszély abban rejlik, hogy esetleg a homopátiás kezelés megfosztja a beteget a szükséges beavatkozásoktól. Jó példa erre éppen a rekedtség, ez az orvosi szempontból fontos tünet, amely rendszerint az alapbetegséggel együtt elmúlik, ám ha megmarad, akkor mögötte rendszerint komoly probléma fedezhető fel. Hasonló a helyzet a lázcsillapítással is, amelynek kiemelt szerepe van a gyermekgyógyászatban. A gyógyszerektől tartó szülők csecsemőknek nemcsak nem szívesen adnak hagyományos lázcsillapítókat, de manapság idegenkednek a fizikai lázcsillapítás, a vizes testpakolás vagy a hütőfürdő régi, jól bevált eszközeitől is. 
Inkább adnak ezek helyett is homeopátiás szereket, abban a meggyőződésben, hogy ez a szer kevésbé viseli meg a csecsemő szervezetét. Holott éppen a hatékony gyógyszeres és fizikai lázcsillapítás hiánya sodorhatja rosszabb állapotba a csecsemőket, kisdedeket.

Szerencsére, a hazai tapasztalatok szerint súlyosabb állapotok esetén kivétel nélkül orvoshoz fordulnak, s a beteg gyermeket alávetik a szükségesnek ítélt beavatkozásoknak. Ilyenkor homeopátiás szereket kizárólag az akut állapot lezajlása után, mintegy a rehabilitációs időszakban adják a gyermek felerősítése, a lezajlott betegség vagy a beavatkozások utóhatásainak csökkentése céljából. Ekkor nagy valószínűséggel életbe lép a fent említett placebohatás is, hiszen egy meggyógyított beteget tovább gyógyítani igen hálás és látványos feladat. Egy anya mesélte, hogy szívmütéten átesett gyermeke milyen sokáig volt súlyos állapotban, élet-halál között lebegett, majd további hónapokba telt, mire egyáltalán táplálni vagy mozgatni lehetett. Mintegy fél év múlva vihette haza. „Otthon - mesélte kizárólag homeopátiás gyógyszereket adtam neki. Ami a kórházban nem sikerült, és lehetetlennek látszott, az otthon a homeopátia segítségével szinte hetek alatt megtörtént: a gyerek enni kezdett, jobb lett a kedve, mozgott és figyelt, olyan volt, mintha kicserélték volna." Nehéz azonban nem arra gondolni, hogy egy sikeres szívmütét utáni jobb oxigenizáció, majd a hospitalizáció megszüntetése s a gondos anyai ápolás legalább akkora szerepet játszhatott a szerencsés javulásban, mint a homeopátiás szerek.

Egy másik család arról számolt be, hogy gyermekük epilepsziáját a legjobb orvosok a legjobb gyógyszerekkel sem tudták befolyásolni, maximum annyit értek el, hogy a napi negyvenes rohamszám húszra mérséklődött. „Ekkor elhagytuk a gyógyszereket, és speciális ketogén diétába kezdtünk, ami szintén nem használt. Visszatértünk a gyógyszerekre, és kísérleteztünk többféle természetgyógyászati módszerrel is, mindhiába. Ezután tértünk át a homeopátiás szerekre. Átmeneti kis javulás után azonban sajnos ott tartunk, ahonnan indultunk, de legalább nem mérgezzük tovább a gyereket a hatástalan gyógyszerekkel."

Tehát elmondható, hogy mind a gyógyszerészek meglátásai, mind a szülők beszámolói alapján a homeopátiát a szülők kívánatos, „szelíd” gyógymódnak tartják mind egészséges gyermekeik mindennapos betegségei során, mind pedig a megelőzés szakaszában („Beoltattam ugyan a gyereket influenza ellen, de utána egész télen adtam neki a homeopátiás immunerősítőt, nem is volt beteg egy napot se, még egy náthája se volt egész télen!'), illetve betegségek utáni időszakokban. Nem foglalkoznak sokat annak elemzésével, hogy mi hatott valójában, mitől gyógyult meg a gyermek vagy mi gátolta meg a betegség kialakulását: idő, természetes gyógyulás, egyéb, párhuzamosan adagolt gyógyszerek stb. Sok család szereti egyszerüen azért, mert jól illeszkedik a természetes dolgokhoz ragaszkodó, környezettudatos életfelfogáshoz, könnyen beszerezhető, nem is túl drága és legfőképpen ártalmatlan, mellékhatásoktól mentes, biztonságos szer. 
Magyarországon a gyógyszertárakban számos, hivatalosan is befogadott, sőt egyes esetekben csak orvos által felírható homeopátiás készítmény érhető el. Ezeket elsősorban nagy külföldi (főleg német) cégek állítják elő és reklámozzák. Szinte minden problémára, tünetre található Materia Medica-alapú készítmény, többnyire könnyen bevehető, színes cukorgolyók formájában, de akad kúp, kenőcs, szirup, sőt, injekció is. Ha biztosított, hogy ez a kezelés nem valamely orvosilag indokolt, illetve szükséges terápiás beavatkozás helyett történik, valószínüleg kevés kárt okoz, és az sem kizárt, hogy a test és lélek rejtekútjain keresztül még hatásos is lehet...

Ugyanakkor ne higgyük el a Varázshegy Naphtájának, hogy „A tudomány is csak hit, mint akármi más, csak rosszabb és ostobább minden más hitnél”, hanem valljuk Settembrinivel: „Ahol az embernek már nincs erkölcsi bátorsága ítélkezni és különbséget tenni csalás és valóság között, ott vége az életnek általában, az ítéletnek, az értéknek, a haladást elősegítő tettnek ..."

\section{HOMEOPÁTIÁS SZÓGYŰJTEMÉNY (HAHNEMANN ÉS A MAI INTERNETES „TÁJÉKOZTATÓK” ALAPJÁN)}

antidótum: a homeopátiás kezelést, az életerő gyógyító hatását megakadályozó anyag, mint például a kávé, az alkohol, a dohányzás, a parfümök vagy a házi tisztítószerek

homeopátiás bizonyitás (proving): a homeopátiás Materia Medica alapanyagainak kiválasztását szolgáló módszer, amelynek során egészséges emberek veszik be a kiválasztott tömény anyagokat, majd a kifejlődő tünetek alapján kerül be egy-egy anyag a hasonló tünetek gyógyítására szolgáló készítmények közé dinamizálás: lásd potenciálás

életerő (vital force): az élő szervezet szellemi lényege, amelynek károsodása okozza a homeopátia szerint a betegségek kialakulását. (Hahnemann: the material organism, without the vital force, is capable of no sensation, no function, no self-preservation, it derives all sensation and performs all the functions of life solely by means of the immaterial being [the vital principle] which animates the material organism in health and in disease. [Hahnemann: Organon $\S 10,6^{\text {th }}$ ed. $\left.]\right)$

Materia Medica: a homeopátiában alkalmazott gyógyhatású alapanyagok gyüjteménye, amelyek az őstinktúrát vagy ősoldatot (ezek lehetnek növényi nedvek, állati mérgek vagy váladékok, ásványi oldatok vagy porok) biztosítják a hígításokkal dinamizált, potenciált készítményekhez. A Materia Medica néhány általánosan használt alapanyaga például az árnika, a belladonna (nadragulya), a kamilla, a konyhasó, a réz, a sisakvirág vagy a vadgesztenye. A hígított, dinamizált készítményeket általában apró cukorgolyókra (globulusokra) csep- 
pentik, mert ilyen formában könnyen adagolhatók, de alkalmazhatók tabletták, kenőcsök, kúpok, akár injekciók formájában is.

miazma: a betegségek alapja, amely fertőzéshez hasonlóan léphet az emberi testbe, vagy már a születéskor jelen lehet, és szunnyadó állapotban van, amíg egy egészségre káros életmód, trauma vagy emóció nem aktiválja. A miazma elöször tüneteket, majd betegséget okoz.

nozód, szarkód: kisebb szövetdarab, amely homeopátiás készítmény alapját szolgáltatja. A nozód „fertőzött”, beteg szövet, amely megdarálás után kerül folyamatos hígításra. A szarkód egészséges szövetből származik, és hasonló módon kerül alkalmazásra.

Organon: az Organon der rationellen Heilkunde Samuel Hahnemann 1810ben, eredetileg németül publikált könyve, amely leírja a homeopátia alapjait. A könyv több nyelven, hat kiadásban jelent meg.

potencia: a homepátiás készítmény potenciája a fokozatos hígítások mértékére utal. A homeopátiás potencia a hígítások mértékének közvetlen függvénye, mivel az eredeti anyag egyre kisebb mennyisége érheti el a kívánt hatást. Így a „magas potenciájú” homeopátiás szer igen nagyszámú, jelentős hígításon esett át.

potenciálás, dinamizálás: egy gyógyszer életerejének, gyógyhatásának növelése speciálisan elvégzett (szukkusszió vagy trituráció) hígításokkal. A dinamizálás során legalább tíszer, de akár több százszor is sorozatosan 1:10 (jele $\mathrm{X}$ ) vagy 1:100 (jele C) mértékü hígítást kell végezni. A sorozathígítás során az előző hígításból kell $1 / 10$ vagy $1 / 100$ résznyi anyagot kivenni, és azt tovább hígítani. A megfelelő módon (ütve rázás, dörzsölés) elvégzett hígítások a homeopátia gyakorlói szerint felszabadítják és megsokszorozzák az eredeti anyagban lévő gyógyító erőt.

szukkusszió (ütve rázás): a frissen hígított oldat rázogatása az edény kemény, de rugalmas tárgyhoz történő ütögetésével. Hahnemann elképzelése szerint ez a folyamat szabadítja fel a gyógyhatáshoz szükséges dinamikus erőket.

trituráció (dörzsölés): por alakú anyag eldörzsölése többnyire tejcukorral (laktózzal) mozsárban, a megfelelő dörzsölővel. Ez alkotja a további hígításokhoz szükséges alapanyagot, illetve így kell a további hígításokat is létrehozni. A homeopátia elvei szerint ez jelenti a hatóanyag dinamizálását.

\section{IRODALOM}

Carlston, M. (2011): Homeopathy. In: Micozzi, M. (ed.): Fundamentals of Complementary and Alternative Medicine. $4^{\text {th }}$ ed. St. Louis: Saunders, 343-354.

Davenas, E. - Beauvais, F. - Amara, J. et al. (1988): Human Basophil Degranulation Triggered by Very Dilute Antiserum against IgE. Nature, 338, 816-818. DOI: 10.1038/333816a0, https:// 
www.researchgate.net/publication/20701366_Human_basophil_degranulation_triggered_by_ very_dilute_antiserum_against_IgE

EASAC (European Academies Science Advisory Council) (2017): Homeopathic Products and Practices: Assessing the Evidence and Ensuring Consistency in Regulating Medical Claims in the EU. EASAC, https://easac.eu/publications/details/homeopathic-products-and-practices/

Ernst, E. (1990): Is Homoeopathy a Placebo? British Journal of Clinical Pharmacology, 30, 173174. https://www.ncbi.nlm.nih.gov/pmc/articles/PMC1368214/

Ernst, E. (2005): Is Homeopathy a Clinically Valuable Approach? Trends in Pharmacological Sciences, 26, 11, 547-548. DOI: 10.1016/j.tips.2005.09.003, https:/www.researchgate.net/publication/7598340_Is homeopathy_a_clinically valuable_approach

Falus A. (2004): Homeopathy and High Dilutions - Is There a Real Effect? Inflamatory Research, 53, 179-180. DOI: 10.1007/s00011-003-1241-9

Finniss, D. G. - Kaptchuk, T. J. - Miller, F. et al. (2010): Placebo Effects: Biological, Clinical and Ethical Advances. The Lancet, 375, 686-695. DOI:10.1016/S0140-6736(09)61706-2, https:// www.ncbi.nlm.nih.gov/pmc/articles/PMC2832199/pdf/nihms169379.pdf

Freeman, L (2009). Homeopathy: Like Cures Like. In: Freeman, L. (ed.): Mosby's Complementary and Alternative Medicine: A Research-Based Approach, $3^{\text {rd }}$ ed., St. Louis: Mosby Elsevier, 347-363.

Gensini, G. F. - Conti, A. A. - Conti, A. (2005): Past and Present of "what will please the lord": An Updated History of the Concept of Placebo. Minerva medica, 96, 2, 121-124.

Hahnemann, S. (1810): Organon der rationellen Heilkunde. https://archive.org/details/organonderration00hahn

Hippokratész: Az emberi belső térröl. (ford. Oláh Andor), http://www.orvostortenelem.hu/tankonyvek/tk-05/pdf/2.3.3.1/1966_038_39_olah_andor_hippokratesz_valogatott.pdf_

Jonas, W. - Kaptchuk, T. - Linde, K. (2003): A Critical Overview of Homeopathy. Annals of Internal Medicine, 393-399. https://www.researchgate.net/publication/231584212_A_Critical Overview_of_Homeopathy

Lange, A. (2013): Homeopathy. In: Pizzorno, J. E. - Murray, M. T. (eds.): Textbook of Natural Medicine. $4^{\text {th }}$ ed. St. Louis: Mosby, 314-326.

Maddox, J. - Randi, J. - Stewart, W. (1988): "High-dilution" Experiments a Delusion. Nature, 334, 6180, 287-291. DOI: 10.1038/334287a0, https://www.researchgate.net/publication/20700004 High_Dilution_Experiments_a_Delusion

NHMRC - Australian Government National Health and Medical Research Council (2015): NHMRC Information Paper: Evidence on the Effectiveness of Homeopathy for Treating Health Conditions. Canberra: National Health and Medical Research Council; 2015, https://www.nhmrc. gov.au/guidelines-publications/cam02

Reiner, J. H. (1982): Psionic Medicine. London: Routledge and Kegan Paul

Ross, M. - Olson, J. M. (1981): An Expectancy-attribution Model of the Effects of Placebos. Psychological Review, 88, 408-437. DOI: 10.1037/0033-295X.88.5.408, https://www.researchgate.net/publication/16174117_An_expectancy-attribution_model_of_the_effects_of_placebos

Science Jokes - Chemistry. https://jcdverha.home.xs4all.nl/scijokes/3_5.html

Shang, A. - Huwiler-Müntener, K. - Nartey, L. et al. (2005): Are the Clinical Effects of Homoeopathy Placebo Effects? Comparative Study of Placebo-controlled Trials of Homoeopathy and Allopathy. The Lancet, 366, 9487, 726-732. DOI: 10.1016/S0140-6736(05)67878-6, https:// www.thelancet.com/journals/lancet/article/PIIS0140673605678786/fulltext

Thomas, R. - Shealy, C. N. (eds.) (1996): The Complete Family Guide to Alternative Medicine. New York: Barnes and Noble Books 
Vandenbroucke, J. P. (2005): Homoeopathy and "the growth of truth". The Lancet, 366, 691-692. DOI: 10.1016/S0140-6736(05)67151-6, https://www.researchgate.net/publication/7229202_Homeopathy_and_The_Lancet

Zhang, X. (2001): Legal Status of Traditional Medicine and Complementary/Alternative Medicine: A Worldwide Review. World Health Organization. Geneva, Switzerland: Traditional Medicine World Health Organization, http://apps.who.int/medicinedocs/pdf/h2943e/h2943e.pdf

URL1: https://web.archive.org/web/20070808051016/http:/altmed.creighton.edu/Homeopathy/ history.htm 